\title{
Compositional change in fish assemblages along the Andean piedmont - Llanos floodplain gradient of the río Portuguesa, Venezuela
}

\author{
David J. Hoeinghaus*, Kirk O. Winemiller* and Donald C. Taphorn**
}

The Llanos is an extensive area of savannas and floodplains in central and western Venezuela that encompasses a gradual elevation gradient from the río Orinoco to the foothills of the Andean piedmont. The río Portuguesa is one of the major rivers in this region that until recently had escaped major anthropogenic impacts and still maintains substantial seasonal fish migrations. However, little work has been conducted on fish ecology in this river. The present study analyzes museum collections sampled at 28 locations along the longitudinal gradient of the río Portuguesa to assess similarity of species composition from the foothills of the Andean piedmont to the lowland llanos floodplain. The standardized samples used in this analysis contained greater than 133 species representing 6 orders and 27 families, dominated by characiforms (61 species) and siluriforms (52 species). Detrended correspondence analysis (DCA) ordination of samples revealed a continual pattern of compositional change, and species are added at a faster rate than they are lost as one moves from the foothills of the piedmont to the low llanos. Based on DCA, samples from three elevational segments were found to significantly differ in fish species composition. Assemblages in the upper reaches contained unique species of loricariid catfishes, small pimelodid and trichomycterid catfishes, and small characiforms not observed at lower elevations. The lowland reach contained species of cichlids, large catfishes and characids not collected from the other two regions. Samples from the middle region revealed transitional species composition. Longitudinal species turnover probably reflects differences in environmental characteristics such as a water velocity, substrate composition and disturbance regime. Findings from this broad-scale analysis contribute to a baseline for future studies of fish ecology in this region.

Llanos corresponde a uma área extensa de savanas e planícies de inundação situadas no centro e no oeste da Venezuela, abrangendo um gradiente de elevação desde o rio Orinoco até a região montanhosa na base da cordilheira dos Andes. O rio Portuguesa é um dos principais rios desta região, até recentemente livre de maiores impactos antropogênicos, mantendo relevantes migrações sazonais de peixes. Apesar disto, poucos estudos sobre ecologia de peixes têm sido conduzidos neste ambiente. O presente estudo analisa coleções de museus amostradas em 28 locais ao longo do gradiente longitudinal do rio Portuguesa, avaliando a similaridade na composição das espécies desde a região montanhosa na base da cordilheira dos Andes até as terras baixas da planície de inundação do Llanos. As amostras padronizadas utilizadas nesta análise continham mais de 133 espécies, representando 6 ordens e 27 famílias, dominadas por caraciformes (61 espécies) e siluriformes (52 espécies). A ordenação das amostras através da análise de correspondência com remoção do efeito do arco (DCA) revelou um padrão contínuo de mudança na composição, com taxa de adição de espécies superior a de perda no sentido base da cordilheira ao baixo Llanos. Com base na DCA, as amostras dos três segmentos com distintas altitudes apresentaram diferenças significativas na composição das espécies de peixes. Assembéias do trecho superior contiveram unicamente espécies de loricarídeos, pimelodídeos de pequeno porte e tricomicterídeos, além de caraciformes de pequeno porte não observados nos segmentos inferiores. O trecho inferior apresentou espécies de ciclídeos, bagres de grande porte e caracídeos não coletados nas outras duas regiões. Amostras do trecho intermediário revelaram uma composição transicional de espécies. A alteração longitudinal na composição de espécies reflete, provavelmente, diferenças nas características ambientais, como: velocidade da água, composição do substrato e regime de distúrbio. Os achados desta análise de ampla-escala podem contribuir como ponto de partida para futuros estudos de ecologia de peixes nesta região.

Key words: longitudinal gradient, migration, ribazón, seasonality, turnover.

\footnotetext{
*Section of Ecology and Evolutionary Biology, Department of Wildlife and Fisheries Sciences, Texas A\&M University, College Station, TX 77843-2258, U.S.A. e-mail: (DJH)djhoeinghaus@tamu.edu; (KOW) k-winemiller@tamu.edu

**Universidad Experimental de Los Llanos Ezequiel Zamora, Guanare, Estado Portuguesa 3310, Venezuela. e-mail: taphorn@cantv.net
} 


\section{Introduction}

The Llanos is an extensive floodplain savanna in central and western Venezuela bordered by the Andes Mountains in the northwest, the Coastal Range (Cordillera de la Costa) to the north, and the Guiana Shield to the southeast. The region encompasses a gradual elevation gradient, from approximately $30 \mathrm{~m}$ above sea level at the río Orinoco to $150 \mathrm{~m}$ above sea level at the foothills of the Andean piedmont. The eastern flank of the Andes and the llanos are drained by left bank tributaries of the río Orinoco, which flows northeast through the center of Venezuela along the edge of the Guiana Shield. Lotic habitats vary across the elevational gradient, with piedmont segments characterized by steeper slopes, faster water velocity, and coarser substrates than low-gradient channels in the llanos (Baskin et al., 1980; Winemiller, 1989c).

The regional climate exhibits strong annual wet (late May to August) and dry (January to early May) seasonality. Average yearly rainfall is $1300 \mathrm{~mm}$, with approximately 850 mm occurring between June and September (Winemiller, 1989a, 1989b). During the dry season, aquatic habitats of the llanos are largely restricted to creek channels, lagoons and remnant floodplain pools. Piedmont streams have reduced discharge during the dry season, and streams in areas of extensive deforestation may dry completely [see Lilyestrom \& Taphorn (1983), Winemiller et al. (1996), and Allan et al. (2002)]. During the wet season, broad expanses of the llanos are inundated, and piedmont streams experience flash floods of short duration (Winemiller, 1989c). White-water tributaries draining the Andes (e.g. río Guanare, río Portuguesa) deposit nutrient-rich alluvial sediments in the llanos during flood periods. During the rainy season, many fishes migrate into lowland rivers, creeks and seasonally flooded terrain where they spawn (Winemiller, 1996). Other species spawn in the main river channel with eggs and larvae passively transported into marginal floodplain habitats.

During the falling-water period, large mixed-species schools called "ribazónes" ascend rivers of western Venezuela from the río Orinoco floodplain and río Apure delta and support an important commercial fishery. BarbarinoDuque et al. (1998) estimated 9,360,000 individuals occupying 9.0 ha along a $2.5 \mathrm{~km}$ stretch of the río Apure. Upstream migrations commence at the onset of the fallingwater period, with school density decreasing as individuals settle out, are caught by fishermen, or are consumed by predators along the gradient. Recently, a combination of deforestation, overfishing, pollution, and river impoundment has had a dramatic effect on the size of ribazónes. BarbarinoDuque et al. (1998) characterized the status of ribazónes in western Venezuela as being either completely eliminated or greatly diminished in almost $80 \%$ of the primary Andean piedmont rivers (only 4 of the 24 rivers surveyed had substantial migrations).

The río Portuguesa is a white-water river in western Venezuela, extending over $300 \mathrm{~km}$ from its confluence with the río Apure in the lowland llanos to the foothills of the Andean piedmont (Fig. 1), and is one of the four rivers surveyed by Barbarino-Duque et al. (1998) that maintained a significant ribazón. Although the Portuguesa is one of the few rivers in western Venezuela that until recently remained in a relatively natural state, little work has been conducted on fish ecology in this river. In the last few years substantial deforestation in the piedmont headwaters has had a major impact, with the river almost drying completely during the most recent dry season. This study analyzes museum archives collected prior to the recent disturbances at 28 locations along the longitudinal gradient of the río Portuguesa to assess similarity of species composition from the edge of the Andean piedmont to the floodplains of the llanos, and tests for possible biotic regions of the río Portuguesa Basin. This study contributes toward a faunal baseline for future studies of fish ecology in this region.

\section{Materials and Methods}

Fish assemblage and field data were obtained from archives of the Museo de Ciencias Naturales de UNELLEZ (MCNG), Guanare, Estado Portuguesa, Venezuela. Sampling locations ranged from the low llanos near Camaguan in Estado Guarico (ca. $50 \mathrm{~m}$ elevation) to the foothills of the Andean piedmont (ca. 200 m elevation) northeast of Guanare, Estado Portuguesa (Fig. 1). Samples were included only if they fulfilled two primary requirements: 1) similar sampling methodology, and 2) high resolution location data (i.e. descriptional and/or GPS data). To reduce bias associated with sampling methodology,

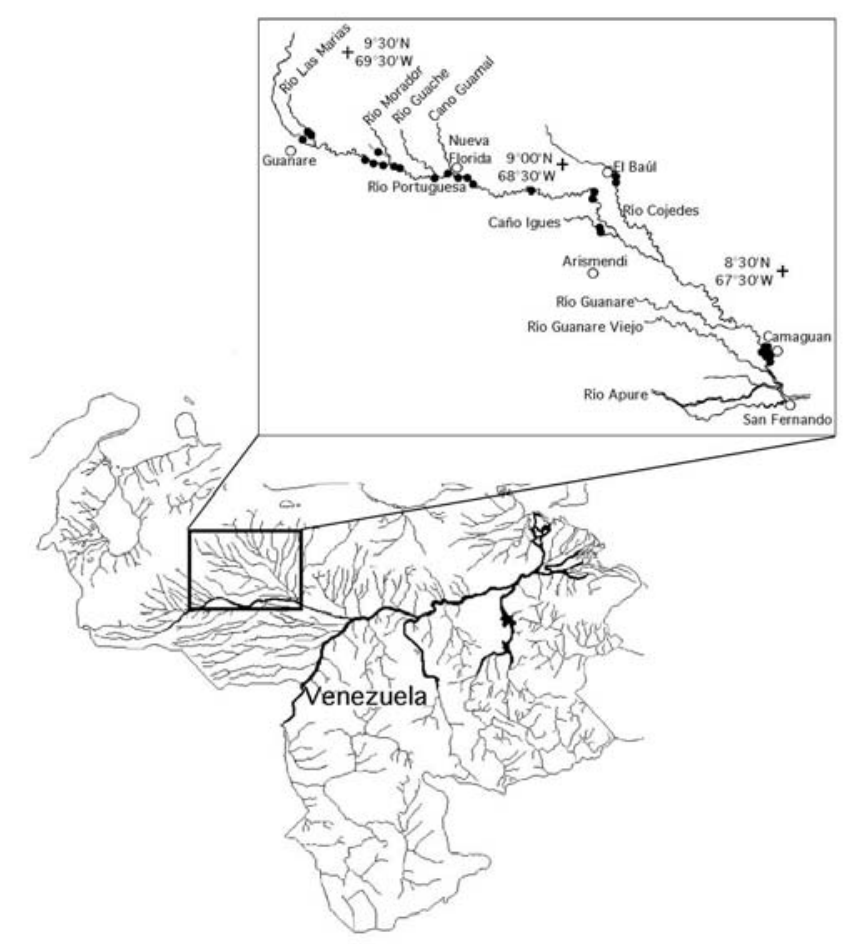

Fig.1. Map of Venezuela with inset showing locations of survey sites $(n=28$, filled circles) along the río Portuguesa elevational gradient. 
presence/absence (i.e. species composition) data from samples collected using seines with mesh sizes between 3.2 and 6.4 mm were analyzed. Consequently, 28 of 37 available survey datasets were included in this analysis. Samples were collected by various researchers between 1981 and 1996 (Appendix A). Undescribed species were labeled by generic name only (e.g. Hyphessobrycon sp.). For cases in which species identity was questionable or unknown, all specimens and species within that genus were grouped for purposes of our analyses (e.g. Eigenmannia spp.).

To evaluate compositional similarity among sites, data were analyzed by correspondence analysis (CA) using CANOCO (Version 4, Microcomputer Power). The Guttman effect (arch effect), a mathematical artifact resulting from a systematic relationship between the first axis and subsequent axes, was present in the resulting ordination (likely the combined result of using presence/absence data and strong compositional differences among regions; Hill \& Gauch, 1980; Gauch, 1982; Palmer, 1993; ter Braak \& Smilauer, 1998; Quinn \& Keough, 2002). Detrended correspondence analysis (DCA) was therefore performed to remove the arch. In the DCA, we detrended by segments and the resulting axes are scaled in units of standard deviation (SD), with a half turnover of species in samples occurring in $1 \mathrm{SD}$, and full species turnover in 4 SD (ter Braak \& Smilauer, 1998).

Multivariate analysis of variance (MANOVA) and discriminant function analysis (DFA) were conducted to test for significance of groupings elucidated by DCA. Both analyses were conducted using "region" as a categorical variable and samples scores on the four axes obtained from DCA as dependent variables. Although the third and fourth DCA axes typically explain a very small proportion of the total explained variance (see Results), using variance explained on all DCA axes provides more robust MANOVA and DFA evaluations than using values from the first and second axes alone. DFA predicts region of origin for each sample, with the null hypothesis equal to the percentage of correct predictions expected by chance (in this case approximately $35 \%$ ). Results from DFA are presented as percent correct classification. Both analyses were performed using the statistical package JMP (Version 4.04, SAS Institute Inc.).

\section{Results}

The 28 samples archived at MCNG included in this analysis contained at least 133 species representing 6 orders and 27 families, dominated by characiforms (61 species) and siluriforms (52 species) which together comprised $84 \%$ of all species collected (Appendix B). Most species occurred at relatively few survey sites, with $78 \%$ collected at fewer than $25 \%$ of the sites sampled. The most frequently collected species were the characids Cheirodon pulcher (Gill) and Roeboides dayi (Steindachner) (collected at 17 and 16 sites respectively), followed by siluriforms of the genus Pimelodella and gymnotiforms of the genus Eigenmannia (both collected at 15 sites; Appendix B).

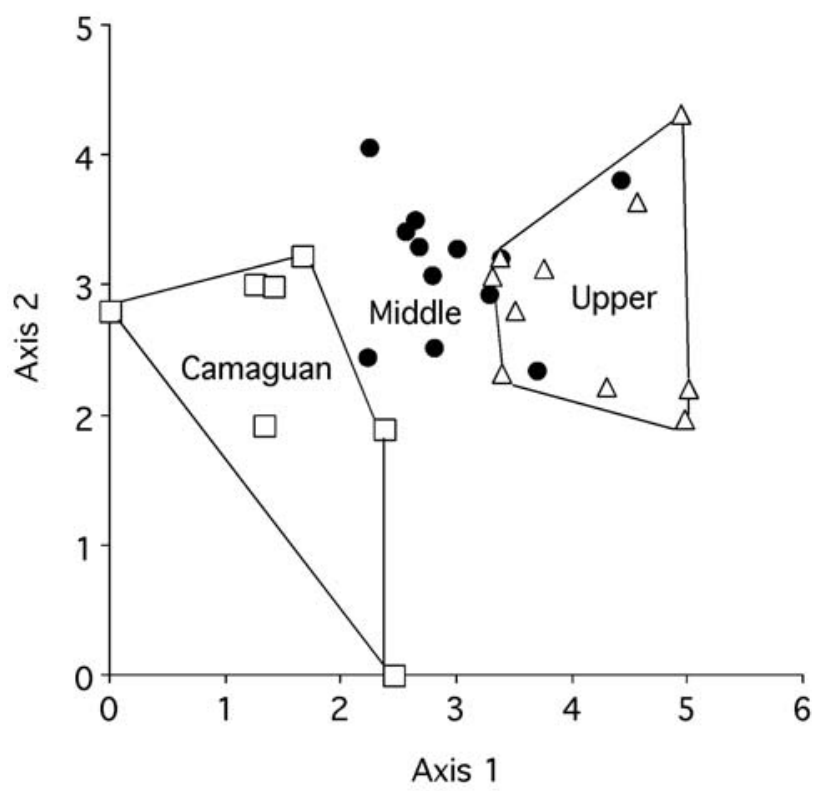

Fig. 2. DCA ordination of species assemblages at survey sites in three different elevational zones along the longitudinal gradient of the Portuguesa River, Venezuela: Camaguan, 50-100 m (open squares); Middle, 100-150 m (filled circles); and Upper, 150-200 m (open triangles). The three regions were significantly different in assemblage composition (MANOVA, $\mathrm{p}<0.0001$ ).

The first two DCA axes are presented for interpretation (axis 1-4 eigenvalues: $0.565,0.363,0.268$, and 0.196 respectively). Ordination of samples by DCA revealed a continuous gradient of assemblage composition along the río Portuguesa longitudinal gradient, with lowland sites (Camaguan) scoring lowest and upland sites (100-200 m) tending to score highest on axis 1 (Fig. 2). Middle elevation sites (100-150 m) tended to have intermediate scores on axis 1 and 2, although there was overlap with upper elevation sites (150-200 m). Overall, the three regions had significantly different DCA loadings (MANOVA, $\mathrm{F}_{8,44}=7.22$, $\mathrm{p}<0.0001$ ), and DFA correctly classified $83 \%$ of samples according to region (null of $35 \%$ correct classification). Divisions between these three regions can be roughly defined as the confluence of the río Guache with the río Portuguesa, and somewhere between the confluence of the río Cojedes with the río Portuguesa and Camaguan (an insufficient spatial distribution of sites was available in the lower reaches of the basin to more closely define the faunal break between the Camaguan and Middle regions, see Fig. 1).

Species composition of the Camaguan region was characterized by the large catfish species Phractocephalus hemioliopterus (Bloch and Schneider), Pseudoplatystoma fasciatum (Linnaeus) and P. tigrinum (Valenciennes) plus large characids such as the "cachama" [Colossoma macropomum (Cuvier)] and "morocoto" [Piaractus brachypomus (Cuvier)] (Table 1). The Camaguan region also has several smaller species that were not collected in middle and upper sites of the basin, including the poeciliid Fluviphylax obscurum (Costa) and 
cichlid species Mesonauta egregius Kullander \& Silfvergrip and Chaetobranchus flavescens Heckel. The apteronotid knifefish Sternarchorhamphus muelleri (Steindachner), a species typically associated with the substrate of main-channels, was only collected from the Camaguan region.

Species characteristic of upper and middle reaches of the Portuguesa Basin included loricariid catfishes [e.g. Lamontichthys llanero Taphorn \& Lilyestrom, Panaque nigrolineatus (Peters), Loricaria cataphracta Linnaeus, and an undescribed species Pseudohemiodon sp.], small pimelodid and trichomycterid catfishes (Imparfinis spp., Cetopsorhamdia sp., Homodiaetus haemomyzon Myers, and Haemomaster venezuelae Myers), and small characiforms (Creagrutus spp., Bryconamericus spp., and Parodon apolinari Myers) (Table 1). Species captured only from the upper region were Parodon apolinari and Cetopsorhamdia sp.

Table 1. Scores and frequencies of occurrence for species scoring highest and lowest values on the first two DCA ordination axes (see also Appendix B).

\begin{tabular}{|c|c|c|c|}
\hline Species & Axis 1 & Axis 2 & $\begin{array}{l}\text { No. } \\
\text { sites }\end{array}$ \\
\hline Mesonauta egregius & -2.00 & 2.71 & 1 \\
\hline Phractocephalus hemioliopterus & -0.83 & 1.39 & 2 \\
\hline Astronotus sp. & -0.78 & 3.10 & 2 \\
\hline Colossoma macropomum & -0.51 & 2.92 & 2 \\
\hline Chaetobranchus flavescens & -0.40 & 2.01 & 3 \\
\hline Pseudoplatystoma fasciatum & -0.40 & 2.01 & 3 \\
\hline Mylossoma duriventre & -0.10 & 3.15 & 3 \\
\hline Piaractus brachypomus & 0.18 & 4.33 & 3 \\
\hline Hydrolycus armatus & 0.44 & 3.51 & 1 \\
\hline Hypophthalmus marginatus & 0.44 & 3.51 & 1 \\
\hline Pseudoplatystoma tigrinum & 0.44 & 3.51 & 1 \\
\hline Acanthopoma bondi & 1.48 & 6.78 & 1 \\
\hline Agamyxis albomaculatus & 1.48 & 6.78 & 1 \\
\hline Bujurquina pulcher & 1.48 & 6.78 & 1 \\
\hline Galeocharax sp. & 1.48 & 6.78 & 1 \\
\hline Ageneiosus vittatus & 2.07 & -1.28 & 1 \\
\hline Fluviphylax pygmaeus & 2.07 & -1.28 & 1 \\
\hline Bryconamericus cismontanus & 4.52 & 4.49 & 4 \\
\hline Astyanax superbus & 4.63 & 4.37 & 3 \\
\hline Homodiaetus haemomyzon & 4.87 & 1.29 & 3 \\
\hline Parodon apolinari & 4.90 & 1.93 & 6 \\
\hline Creagrutus spp. & 5.00 & 3.32 & 11 \\
\hline Bryconamericus sp. & 5.09 & 2.69 & 8 \\
\hline Lamontichthys llanero & 5.23 & 1.72 & 5 \\
\hline Engraulisoma taeniatum & 5.30 & 2.49 & 4 \\
\hline Sternarchorhynchus curvirostris & 5.36 & 1.54 & 3 \\
\hline Imparfinis spp. & 5.37 & 4.25 & 7 \\
\hline Astyanax metae & 5.45 & 5.65 & 2 \\
\hline Sturisoma tenuirostre & 5.51 & 5.47 & 1 \\
\hline Hemibrycon metae & 5.55 & 4.02 & 3 \\
\hline Loricaria cataphracta & 5.55 & 1.80 & 3 \\
\hline Panaque nigrolineatus & 5.65 & 1.45 & 4 \\
\hline Hyphessobrycon sp. & 5.78 & 4.93 & 1 \\
\hline Pseudocetopsis sp. & 5.78 & 4.93 & 1 \\
\hline Pseudohemiodon sp. & 6.14 & 1.35 & 3 \\
\hline Cetopsorhamdia spp. & 6.56 & 1.47 & 4 \\
\hline Haemomaster venezuelae & 6.57 & 1.78 & 1 \\
\hline Hypoclinemus mentalis & 6.57 & 1.78 & 1 \\
\hline Paraloricaria sp. & 6.57 & 1.78 & 1 \\
\hline
\end{tabular}

Samples from the middle region were transitional with most all species also collected from the upper and Camaguan regions. Species composition of the Middle region more closely resembled the Upper region than the Camaguan region (Fig. 2). Several species were only captured in the Middle region, but based on other survey information (Taphorn \& Lilyestrom, 1984; Taphorn, 1992) only two of these seem to be unique to this region (Epapterus blohmi Vari, Jewett, Taphorn \& Gilbert and Galeocharax sp.). The other species that were unique in Middle region surveys are known to occur in low-llanos habitats in Apure [e.g. Agamyxis albomaculatus (Peters), Anostomus ternetzi Fernández-Yépez, Corydoras septentrionalis Gosline, Platynematichthys notatus (Schomburgk), and Potamorhina altamazonica (Cope)]. Two species not collected from the Middle region, Astronotus sp. and Pseudoplatystoma fasciatum, have been collected at other sites within this elevation range within the basin (Winemiller, 1996).

\section{Discussion}

Based mostly on work from North America and Europe, longitudinal gradients of species composition in rivers and streams have long been recognized by aquatic ecologists [e.g. Burton \& Odum (1945); Sheldon (1968); Horwitz (1978); Matthews (1986); Rahel \& Hubert (1991)]. In general, compositional changes have been characterized as distinct faunal breaks or zones reflective of species additions as environmental complexity increases downstream [reviewed in Rahel \& Hubert (1991)]. Patterns generated from temperate systems do not necessarily hold for tropical systems having greater taxonomic and ecological diversity. Yet several studies conducted on Neotropical rivers and streams over the last two decades have found significant patterns of fish assemblage differentiation along longitudinal gradients [e.g., Ibarra \& Stewart (1989); Winemiller \& Leslie (1992); RodilesHernández et al. (1999); Silvano et al. (2000); Abes \& Agostinho (2001); Bistoni \& Hued (2002)].

Our analyses examined fish assemblage composition in three elevational zones along the lower and middle reaches of the río Portuguesa (high Andean and piedmont zones were not included), which we termed the Camaguan (Lower), Middle (high llanos), and Upper regions (high llanos to piedmont transition). Assemblages of the Upper and Middle reaches are distinguished by certain species of small characiforms and siluriforms, especially loricariids. The Camaguan region differs in having more species of large catfishes, characiforms, and cichlids. Species composition in the Middle region was more similar to the Upper region than the Camaguan region. We observed highest species richness in the Middle region, in contrast to previous longitudinal gradient studies that generally have described patterns of increasing species richness in lower river stretches.

This observed pattern of species richness is probably an artifact due to sampling biases (i.e. collecting methods and effort, seasons, and habitats). For example, marginal floodplain 
pools (such as those common in the Camaguan region during the dry season) may shift to piscivore-dominated communities as the dry season progresses and small species are consumed with species diversity declining as a result. Also, some of the collections from the Camaguan region emphasized larger species (field notes of O. Castillo, UNELLEZ), and probably do not provide reliable samples of the complete fish assemblage in the lower reach of the río Portuguesa. Taphorn \& Lilyestrom (1984) surveyed fishes in artificial floodplain pools in the low llanos of Apure, a region with aquatic habitats similar to those in the Camaguan region. They collected over 100 fish species, including most of the species recorded from Camaguan plus several reported only from our Middle region. The Camaguan region probably has highest species richness, and new species appear to be added at a higher rate than species are lost as one moves downstream from the piedmont to the low llanos of Apure. The distinct faunal break between the Camaguan and the Middle region suggested by the DCA ordination probably resulted from both sampling bias and a lack of sites between the Camaguan and Middle region. Data from surveys performed at additional sites in this area would probably yield a more gradual pattern of transition.

Differences in species assemblage composition along the longitudinal gradient of the río Portuguesa probably reflect differences in environmental characteristics. Survey sites located at highest elevations in our Upper region experience flash floods during the wet season, have relatively coarse substrates, and tend to have narrow floodplains. Survey sites at lower reaches had finer substrates, broad floodplains that are seasonally inundated, and more lentic habitats. Several species of algivorous armored catfishes are characteristic of the Upper region, potentially due to preferences for grazing smooth rock surfaces, such as cobble (Flecker, 1997). Ibarra \& Stewart (1989) found greatest species assemblage turnover along the longitudinal gradient in association with major changes in substrate composition (i.e. absence of rock/cobble in lower stretches).

Our results are similar to findings from Baskin et al.'s (1980) study of trichomycterid and cetopsid catfishes in the Portuguesa Basin. They divided the río Portuguesa into three regions based on elevation: piedmont (above $200 \mathrm{~m}$ ), high llanos (between 100 and $200 \mathrm{~m}$ ), and low llanos (below $100 \mathrm{~m}$ ). A single species (Ochmacanthus alternus Myers) was present below $100 \mathrm{~m}$ elevation, with 9 species found above $100 \mathrm{~m}$. While these authors suggested that these species could be competitively excluded from the more diverse lowland areas, they also noted that the variation closely corresponded with a change from faster to slower-moving waters. Silvano et al. (2000) attributed faunal turnover in the Upper río Juruá of Brazil primarily to differences in water flow, as well as habitat specializations for some species (e.g. curimatids adapted for feeding on fine, organic-rich sediments).

Greater species richness of larger species in lower reaches may be associated with a more predictable (i.e. less stochastic) disturbance regime for the major aquatic habitats. Higher gradient upland reaches are more temporally variable and stochastic, and thus are expected to be inhabited by small species efficient at re-colonizing habitats following flash floods or other disturbances such as desiccation [sensu Schlosser (1987)]. In contrast, fish assemblages in tropical floodplain systems undergo seasonal changes determined by physical characteristics of the aquatic habitat and biotic interactions, both of which vary according to hydrological stage (Boujard, 1992; Rodríguez \& Lewis, 1994; Winemiller, 1996; Tejerina-Garro et al., 1998; Arrington, 2002; Hoeinghaus et al., 2003).

Large-scale seasonal migrations of some species during rising- and falling-water periods could have a homogenizing effect on species composition during these periods. Our analysis included samples from different hydrologic periods, which could have reduced spatial variation in assemblage composition. Nevertheless, significantly different regional species compositions were observed. Results from this broadscale approach are applicable to the development of future studies of fish ecology in the río Portuguesa, and the baseline this work provides for research and conservation is especially important in light of recent environmental threats (e.g. piedmont deforestation) within the basin.

\section{Acknowledgements}

We thank TSU Keyla Marchetto for valuable assistance in retrieval of data archived in the Museo de Ciencias Naturales, UNELLEZ. We acknowledge the field survey activities by Aniello Barbarino, Otto Castillo, and Leo Nico that led to datasets that were combined with datasets from our own surveys for the present analysis. David Jepsen and Tamara McGuire assisted with río Portuguesa fish surveys in 1996. Pitágoras Piana and Milza Abelha translated the abstract to Portuguese. We are grateful for comments from Ana Petry and an anonymous reviewer. Funding for some of the surveys was provided by National Geographic grant 5609-96 to the second author. Funding during the period of data analysis was provided by a Society of Wetland Scientists Student Research Grant to the first author and a U.S. Fulbright Fellowship to the second author.

\section{Literature Cited}

Abes, S. S. \& A. A. Agostinho. 2001. Spatial patterns in fish distributions and structure of the ichthyocenosis in the Água Nanci stream, Upper Paraná River Basin, Brazil. Hydrobiologia, 445: 217-227.

Allan, J. D., A. J. Brenner, J. Erazo, L. Fernandez, A. S. Flecker, D. L. Karwan, S. Segnini \& D. C. Taphorn. 2002. Land use in watersheds of the Venezuelan Andes: a comparative analysis. Conservation Biology, 16: 527-538.

Arrington, D. A. 2002. Evaluation of the relationship between habitat structure, community structure, and community assembly in a Neotropical blackwater river. Unpublished Ph.D. Dissertation, Texas A\&M University, College Station, Texas, U.S.A. 122p. 
Barbarino-Duque, A., D. C. Taphorn \& K. O. Winemiller. 1998. Ecology of the coporo, Prochilodus mariae (Characiformes, Prochilodontidae), and status of annual migrations in western Venezuela. Environmental Biology of Fishes, 53: 33-46.

Baskin, J. N., T. M. Zaret \& F. Mago-Leccia. 1980. Feeding of reportedly parasitic catfishes (Trichomycteridae and Cetopsidae) in the Río Portuguesa basin, Venezuela. Biotropica, 12: 182-186.

Bistoni, M. A. \& A. C. Hued. 2002. Patterns of fish species richness in rivers of the central region of Argentina. Brazilian Journal of Biology, 62: 753-764.

Boujard, T. 1992. Space-time organization of riverine fish communities in French Guiana. Environmental Biology of Fishes, 34: 235-246.

Burton, G. W. \& E. P. Odum. 1945. The distribution of stream fish in the vicinity of Mountain Lake, Virginia. Ecology, 26: $182-194$.

Flecker, A. S. 1997. Habitat modification by tropical fishes: environmental heterogeneity and the variability of interaction strength. Journal of the North American Benthological Society, 16: 286-295.

Gauch, H. G. 1982. Multivariate Analysis in Community Ecology. Cambridge University Press, Cambridge, MA, U.S.A., 298p.

Hill, M. O. \& H. G. Gauch. 1980. Detrended correspondence analysis: an improved ordination technique. Vegetatio, 42: 47-58.

Hoeinghaus, D. J., C. A. Layman, D. A. Arrington \& K. O. Winemiller. 2003. Spatiotemporal variation in fish assemblage structure in tropical floodplain creeks. Environmental Biology of Fishes, 67: 379-387.

Horwitz, R. J. 1978. Temporal variability patterns and the distributional patterns of stream fishes. Ecological Monographs, 48: 307-321.

Ibarra, M. \& D. J. Stewart. 1989. Longitudinal zonation of sandy beach fishes in the Napo River Basin, Eastern Ecuador. Copeia, 1989: 364-381.

Lilyestrom, C. G. \& D. C. Taphorn. 1983. Aspectos sobre a biología y conservación de la palambra (Brycon whitei) Myers y Weitzman, 1960. Revista UNELLEZ de Ciencia y Tecnología, 1: 53-59.

Matthews, W. J. 1986. Fish faunal breaks and stream order in the eastern and central United States. Environmental Biology of Fishes, 17: 81-92.

Palmer, M. W. 1993. Putting things in even better order: the advantages of Canonical Correspondence Analysis. Ecology 74(8): 2215-2230.

Quinn, G. P. \& M. J. Keough. 2002. Experimental Design and Data Analysis for Biologists. Cambridge University Press, Cambridge, MA, U.S.A., 537p.

Rahel, F. J. \& W. A. Hubert. 1991. Fish assemblages and habitat gradients in a Rocky Mountain-Great Plains stream: biotic zonation and additive patterns of community change. Transactions of the American Fisheries Society, 120: 319332.
Rodiles-Hernández, R., E. Díaz-Pardo \& J. Lyons. 1999. Patterns in the species diversity and composition of the fish community of the Lacanja River, Chiapas, Mexico. Journal of Freshwater Ecology, 14: 455-467.

Rodríguez, M. A. \& W. M. Lewis. 1994. Regulation and stability in fish assemblages of Neotropical floodplain lakes. Oecologia, 99: 166-180.

Schlosser, I. J. 1987. A conceptual framework for fish communities in small warmwater streams. Pp 17-24. In: Matthews, W. J. \& D. C. Heins (Eds.). Community and Evolutionary Ecology of North American Stream Fishes. University of Oklahoma Press, Norman, OK, U.S.A., 310p.

Sheldon, A. L. 1968. Species diversity and longitudinal succession in stream fishes. Ecology, 49: 193-198.

Silvano, R. A. M., B. D. do Amaral \& O. T. Oyakawa. 2000. Spatial and temporal patterns of diversity and distribution of the Upper Juruá River fish community (Brazilian Amazon). Environmental Biology of Fishes, 57: 25-35.

Taphorn, D. C. 1992. The Characiform Fishes of the Apure River Drainage, Venezuela. BioLlania Special Edition No. 4. Guanare, Venezuela, 537p.

Taphorn, D. C. \& C. G. Lilyestrom. 1984. Los peces del modulo "Fernando Corrales". Resultados ictiologicos del proyecto de investigacion del conicit - pima - 18. Revista Ciencia y Tecníca UNELLEZ, 2: 55-85.

Tejerina-Garro, F. L., R. Fortin \& M. A. Rodríguez. 1998. Fish community structure in relation to environmental variation in floodplain lakes of the Araguaia River, Amazon Basin. Environmental Biology of Fishes, 51: 399-410.

ter Braak, C. J. F. \& P. Šmilauer. 1998. CANOCO Reference Manual and User's Guide to CANOCO for Windows: Software for Canonical Community Ordination (version 4). Microcomputer Power, Ithaca, NY, U.S.A., 351p.

Winemiller, K. O. 1989a. Development of dermal lip protuberances for aquatic surface respiration in South American characid fishes. Copeia, 382-390.

Winemiller, K. O. 1989b. Ontogenetic diet shifts and resource partitioning among piscivorous fishes in the Venezuelan Llanos. Environmental Biology of Fishes, 26: 177-199.

Winemiller, K. O. 1989c. Patterns of variation in life-history among South American fishes in seasonal environments. Oecologia, 81: 225-241.

Winemiller, K. O. 1996. Dynamic diversity in fish assemblages of tropical rivers. Pp 99-132. In: Cody, M. L. \& J. A. Smallwood (Eds.). Long-term Studies of Vertebrate Communities. Academic Press, Orlando, FL, U.S.A., 597p.

Winemiller, K. O. \& M. A. Leslie. 1992. Fish assemblages across a complex, tropical freshwater/marine ecotone. Environmental Biology of Fishes, 34: 29-50.

Winemiller, K. O., C. Marrero \& D. C. Taphorn. 1996. Perturbaciones causadas por el hombre a las poblaciones de peces de los llanos y del piedemonte Andino de Venezuela. Biollania, 12: 13-48.

Received April, 2004 Accepted June, 2004 
Appendix A. MCNG designation, date collected, and location for each collection included in the analyses. Dashed lines separate samples from the Camaguan, Middle and Upper regions.

\begin{tabular}{|c|c|c|}
\hline MCNG Label & Date & Location \\
\hline DCT $85-55$ & 22-Mar-81 & $\begin{array}{l}\text { Camaguan pool ca. } 17 \mathrm{~km} \mathrm{~N} \text { of San } \\
\text { Fernando de Apure }\end{array}$ \\
\hline OCI82-4 & 21-Jan-82 & Río Camaguan, Fundo los Jagues \\
\hline OC84-902 & 09-Aug-84 & $\begin{array}{l}\text { Río Camaguan near CANTV } \\
\text { transmission tower }\end{array}$ \\
\hline OCVI82-19 & 22-Jun-82 & $\begin{array}{l}\text { Río Camaguan near CANTV } \\
\text { transmission tower }\end{array}$ \\
\hline OCI82-3 & 14-Jan-82 & Río Camaguan, KM 271 \\
\hline OCI82-2 & 11-Jan-82 & Río Camaguan, km 271 \\
\hline OC $82-1$ & $11-J a n-82$ & Río Camaguan, Fundo los Chorros \\
\hline$\overline{\mathrm{K}} \overline{\mathrm{OW}} \overline{\mathrm{W}} \overline{\mathrm{C}}-\overline{\mathrm{7}}$ & $13-$ Aug- 96 & Igues Creek at Hwy 8 \\
\hline KOW96-9 & 14-Aug-96 & $\begin{array}{l}\text { Río Portuguesa } 0.5 \mathrm{~km} \text { upstream of } \\
\text { Caño Guayabo }\end{array}$ \\
\hline KOW96-8 & 14-Aug-96 & $\begin{array}{l}\text { Caño Guayabo near Hwy } 8 \text { bridge with } \\
\text { Río Portuguesa }\end{array}$ \\
\hline KOW96-10 & 15-Aug-96 & at El Baul \\
\hline DCT84-84 & $06-O c t-84$ & Caño Igues, $\mathrm{N}$ of Arismendi \\
\hline DCT84-87 & $06-O c t-84$ & $\begin{array}{l}\text { Río Tinaco at El Baul and confluence } \\
\text { With Río Cojedes }\end{array}$ \\
\hline KOW96-5 & 10-Aug-96 & $\begin{array}{l}\text { Small creek, Río Portuguesa W bank, } \\
\text { near Nueva Florida }\end{array}$ \\
\hline DCT84-11 & 22-Jan-84 & $\begin{array}{l}\text { Río Portuguesa at La Aduana, ca. } 40 \\
\mathrm{~km} \text { E of Papelón }\end{array}$ \\
\hline KOW96-3 & 09-Aug-96 & Caño Cocito near Nueva Florida \\
\hline KOW96-6 & 11-Aug-96 & Caño Guamal near Nueva Florida \\
\hline DCT $84-10$ & 22-Jan-84 & $\begin{array}{l}\text { Caño Salado ca. } 5 \mathrm{~km} \mathrm{~S} \text { of Nueva } \\
\text { Florida }\end{array}$ \\
\hline KOW96-4 & 10-Aug-96 & $\begin{array}{l}\text { Río Portuguesa above confluence } \\
\text { with Río Guache }\end{array}$ \\
\hline DCT86-1 & 15-Jan-86 & $\begin{array}{l}\text { Río Las Marías at Rt. } 5 \text { bridge, NE of } \\
\text { Guanare }\end{array}$ \\
\hline KOW96-2 & 08-Aug-96 & $\begin{array}{l}\text { Río Portuguesa at Rt. } 5 \text { bridge, E of } \\
\text { Guanare }\end{array}$ \\
\hline LN84-66 & $13-$ Oct- 84 & $\begin{array}{l}\text { Small creek ca. } 6 \mathrm{~km} \text { downstream from } \\
\text { La Quebrada }\end{array}$ \\
\hline DCT93-2 & 01-Jan-93 & Río Portuguesa in Mata Larga \\
\hline LN84-64 & $12-O c t-84$ & $\begin{array}{l}\text { Río Portuguesa ca. } 3 \mathrm{~km} \text { upstream } \\
\text { from La Quebrada }\end{array}$ \\
\hline LN84-65 & $13-$ Oct- 84 & $\begin{array}{l}\text { Río Portuguesa ca. } 3 \mathrm{~km} \text { downstream } \\
\text { from La Quebrada }\end{array}$ \\
\hline LN84-68 & $14-O c t-84$ & Slough upstream from La Quebrada \\
\hline DCT84-23 & 10-Mar-84 & $\begin{array}{l}\text { Caño Mamon ca. } 9 \mathrm{~km} \text { SE of Rt. } 5 \\
\text { towards La Quebrada }\end{array}$ \\
\hline DCT84-66 & 08-May-84 & $\begin{array}{l}\text { Río Las Marías just below Rt. } 5 \\
\text { bridge }\end{array}$ \\
\hline
\end{tabular}

Appendix B. Combined species list from all sites ( $\mathrm{n}=28)$ and frequency of occurrence. Some species are grouped by genus due to limited taxonomic resolution for some specimens.

Order $(\mathrm{n}=6)$

Family $(n=27)$

Characiformes

Anostomidae

Anostomidae

Anostomidae

Anostomidae

Anostomidae

Characidae

Characidae

Characidae

Characidae

Characidae
Characidae

Characidae

Characidae

Characidae

Characidae

Characidae

Characidae

Characidae

Characidae

Characidae

Characidae

Characidae

Characidae

Characidae

Characidae

Characidae

Characidae

Characidae

Characidae

Characidae

Characidae

Characidae

Characidae

Characidae

Characidae

Characidae

Characidae

Characidae

Characidae

Characidae

Characidae

Characidae

Characidae

Characidae

Characidae

Characidae

Characidae

Crenuchidae

Curimatidae

Curimatidae

Curimatidae

Curimatidae

Curimatidae

Cynodontidae

Erythrinidae

Erythrinidae

Gasteropelecidae

Lebiasinidae

Parodontidae

Parodontidae

Prochilodontidae

Gymnotiformes

Apteronotidae

Apteronotidae

Apteronotidae

Apteronotidae

Apteronotidae

Gymnotidae

Rhamphichthyidae

Sternopygidae

Sternopygidae

Siluriformes

Aspredinidae

Auchenipteridae

Auchenipteridae

Auchenipteridae

Auchenipteridae

Auchenipteridae

Callichthyidae

Callichthyidae
Astyanax superbus 3

Brycon whitei 3

Bryconamericus beta 10

Bryconamericus cismontanus 4

Bryconamericus sp. 8

Charax notulatus 6

Cheirodon pulcher $\quad 17$

Cheirodontops geayi 8

Colossoma macropomum 2

Creagrutus spp. 11

Ctenobrycon spilurus $\quad 10$

Cynopotamus bipunctatus 4

Engraulisoma taeniatum 4

Galeocharax sp. 1

Gephyrocharax valenciae $\quad 14$

Hemibrycon metae 3

Hemigrammus marginatus 2

Hemigrammus micropterus 1

Hemigrammus newboldi 1

Hemigrammus sp. 5

Hyphessobrycon sp. 1

Markiana geayi 4

Moenkhausia copei

Moenkhausia dichroura

Mylossoma duriventre

Paragoniates alburnus

Piaractus brachypomus

Poptella compressa

Pygocentrus cariba

Roeboides affinis

Roeboides dietonito

Serrasalmus irritans

Serrasalmus medinai

Serrasalmus rhombeus

Tetragonopterus argenteus

Triportheus spp.

Xenagoniates bondi

Characidium spp.

Curimata cerasina

Cyphocharax spilurus

Potamorhina altamazonica

Psectrogaster ciliata

Steindachnerina argentea

Hydrolycus armatus

Hoplerythrinus unitaeniatus

Hoplias malabaricus

Thoracocharax stellatus

Pyrrhulina lugubris

Parodon apolinari

Parodon sp.

Prochilodus mariae

Adontosternarchus devenanzi 2

Apteronotus albifrons

Apteronotus bonapartii

Sternarchorhamphus muelleri

Sternarchorhynchus curvirostris

Gymnotus carapo

Rhamphichthys marmoratus 4

Eigenmannia spp.

Sternopygus macrurus

Bunocephalus amaurus

Ageneiosus magoi

Auchenipterus ambyiacus

Entomocorus gameroi

Epapterus blohmi

Parauchenipterus galeatus

Corydoras habrosus

Corydoras septentrionalis 


\begin{tabular}{|c|c|}
\hline Callichthyidae & Hoplosternum littorale \\
\hline Cetopsidae & Pseudocetopsis sp. \\
\hline Doradidae & Agamyxis albomaculatus \\
\hline Doradidae & Oxydoras sifontesi \\
\hline Doradidae & Platydoras costatus \\
\hline Loricariidae & Chaetostoma milesi \\
\hline Loricariidae & Cochliodon plecostomoides \\
\hline Loricariidae & Farlowella mariaelenae \\
\hline Loricariidae & Farlowella vittata \\
\hline Loricariidae & Hypoptopoma steindachneri \\
\hline Loricariidae & Hypostomus spp. \\
\hline Loricariidae & Lamontichthys llanero \\
\hline Loricariidae & Lasiancistrus mystacinus \\
\hline Loricariidae & Liposarcus multiradiatus \\
\hline Loricariidae & Loricaria cataphracta \\
\hline Loricariidae & Loricariichthys brunneus \\
\hline Loricariidae & Nannoptopoma spectabilis \\
\hline Loricariidae & Panaque nigrolineatus \\
\hline Loricariidae & Paraloricaria sp. \\
\hline Loricariidae & Pseudohemiodon sp. \\
\hline Loricariidae & Rineloricaria caracasensis \\
\hline Loricariidae & Sturisoma tenuirostre \\
\hline Pimelodidae & Cetopsorhamdia spp. \\
\hline Pimelodidae & Hemisorubim platyrynchos \\
\hline Pimelodidae & Heptapterus rosae \\
\hline Pimelodidae & Hypophthalmus marginatus \\
\hline Pimelodidae & Imparfinis spp. \\
\hline Pimelodidae & Leiarius marmoratus \\
\hline Pimelodidae & Phractocephalus hemioliopterus \\
\hline Pimelodidae & Pimelodella spp. \\
\hline Pimelodidae & Pimelodus blochii \\
\hline Pimelodidae & Pimelodus ornatus \\
\hline Pimelodidae & Platynematichthys notatus \\
\hline Pimelodidae & Pseudopimelodus apurensis \\
\hline Pimelodidae & Pseudoplatystoma fasciatum \\
\hline Pimelodidae & Pseudoplatystoma tigrinum \\
\hline Pimelodidae & Rhamdia quelen \\
\hline Pseudopimelodidae & Microglanis iheringi \\
\hline Trichomycteridae & Acanthopoma bondi \\
\hline Trichomycteridae & Haemomaster venezuelae \\
\hline Trichomycteridae & Homodiaetus haemomyzon \\
\hline Trichomycteridae & Ochmacanthus alternus \\
\hline Trichomycteridae & Vandellia cirrhosa \\
\hline \multicolumn{2}{|l|}{ Cyprinodontiformes } \\
\hline Poeciliidae & Fluviphylax obscurum \\
\hline Poeciliidae & Poecilia reticulata \\
\hline Rivulidae & Rachovia maculipinnis \\
\hline \multicolumn{2}{|l|}{ Perciformes } \\
\hline Cichlidae & Astronotus sp. \\
\hline Cichlidae & Bujurquina pulcher \\
\hline Cichlidae & Caquetaia kraussii \\
\hline Cichlidae & Chaetobranchus flavescens \\
\hline Cichlidae & Cichlasoma orinocense \\
\hline Cichlidae & Crenicichla geayi \\
\hline Cichlidae & Crenicichla sp. \\
\hline Cichlidae & Mesonauta egregius \\
\hline \multicolumn{2}{|l|}{ Pleuronectiformes } \\
\hline Achiridae & Hyросlineтиs mentalis \\
\hline
\end{tabular}

